The Myth of Evil 



\section{The Myth of Evil}

\section{Phillip Cole}


(C) Phillip Cole, 2006

Edinburgh University Press Ltd 22 George Square, Edinburgh

Typeset in 10/13 Melior by TechBooks India, and printed and bound in Great Britain by Antony Rowe Ltd, Chippenham, Wilts

A CIP record for this book is available from the British Library

ISBN-10 0748622004 (hardback)

ISBN-139780748622009

The right of Phillip Cole to be identified as author of this work has been asserted in accordance with the Copyright, Designs and Patents Act 1988. 